\title{
Petrology and Geochemistry of Basalts from Tonnge Area, Tigyaing Township, Sagaing Region, Myanmar
}

\author{
Myo Min Tun ${ }^{1 *}\left(\mathbb{0}\right.$, Myo Theingi $^{2}$, San Yee Khaing ${ }^{3}$, Thet Naing ${ }^{4}$, Zar Oo Sann ${ }^{5}$, Aung Kyaw Thin ${ }^{6}$ \\ ${ }^{1}$ Department of Geology, Yadanabon University, Mandalay, Myanmar \\ ${ }^{2}$ Department of Geology, Loikaw University, Loikaw, Myanmar \\ ${ }^{3}$ Department of Earth Resources Engineering, Kyushu University, Fukuoka, Japan \\ ${ }^{4}$ Department of Geology, Pathein University, Pathein, Myanmar \\ ${ }^{5}$ Department of Geology, Defence Services Technological Academy, Pyin Oo Lwin, Myanmar \\ ${ }^{6}$ Banmaw University, Banmaw, Myanmar \\ Email: *mintunmyo@gmail.com
}

How to cite this paper: Tun, M.M. Theingi, M., Khaing, S.Y., Naing, T., Sann, Z.O. and Thin, A.K. (2019) Petrology and Geochemistry of Basalts from Tonnge Area, Tigyaing Township, Sagaing Region, Myanmar. Open Journal of Geology, 9, 516-526. https://doi.org/10.4236/ojg.2019.99034

Received: August 16, 2019

Accepted: September 14, 2019

Published: September 17, 2019

Copyright (C) 2019 by author(s) and Scientific Research Publishing Inc. This work is licensed under the Creative Commons Attribution International License (CC BY 4.0).

http://creativecommons.org/licenses/by/4.0/

cc) (i) Open Access

\begin{abstract}
Tonnge basalt is a relatively small basaltic field situated in the Tigyaing Township, Sagaing Region, Myanmar. This basaltic field is considered as one of the occurrences of younger extrusive rocks along the major strike-slip fault of central Myanmar. The basaltic lava flows erupted and rested upon the Upper Miocene-Pliocene Irrawaddy Sandstone. Petrological and geochemical studies of the Tonnge basalts have not been carried out yet. This paper reports the results of petrological and geochemical investigation on the basalts from Tonnge area. These data have provided insight into the origin and petrogenetic processes during evolution. The petrographic characteristics of the basalts have been studied using polarizing microscope. The major- and trace-element compositions of basalt samples were analyzed using X-Ray Fluorescence. The Tonnge basalts are porphyritic, holocrystalline and consist of phenocrysts of olivine, plagioclase \pm clinopyroxene which are set in the fine-grained intergranular groundmass of olivine, pyroxene, and opaque minerals. The basalts show typical characters of alkali olivine basalts. Trace element assemblage of the studied basalts plots on various discrimination diagrams as within-plate basalt erupted in the continental setting. A relatively small volume, monogenetic nature and unique geochemical characteristics of the basaltic lavas suggest that they are derived from a single, short-lived, discrete parental magma as a result of partial melting.
\end{abstract}

\section{Keywords}

Tonnge, Olivine Basalt, Within-Plate, Partial Melting 


\section{Introduction}

Myanmar is located in the eastern marginal zone of India-Asia collision and marked by a prominent still-active dextral Sagaing Fault which connects the eastern Himalayan Syntaxis to the north and the Andaman Sea to the south [1] [2] [3]. This major strike-slip fault medially divides Myanmar into the eastern part (Shan-Thai Block) and the western part (West Burma Block) [4]. The former consists of the Shan Plateau, the Mogok Metamorphic Belt and the Shan Scarps, whereas the later comprises the Indo-Burma Range, the Wuntho-Popa magmatic arc and overlying Cretaceous-Paleogene sediments [3] [5] (Figure $1(\mathrm{a}))$.

Cenozoic magmatism is one of the prominent features in the geologic history of Myanmar. Magma generation processes are related to the India-Asia collision that was commenced during Early Eocene and associated regional plate reorganization, a transition from oblique subduction to dextral movement in Miocene, and subsequent "rollback" of the subducted Indian oceanic lithosphere in the Quaternary [3]. Based on geochronological data from the previous studies [3] [6] [7], the volcanic centers in the central Myanmar are mostly recognized as Quaternary in age.

Tonnge basalt is considered to be one of the occurrences of younger extrusive rocks along the dextral Sagaing Fault of central Myanmar. It is an intraplate

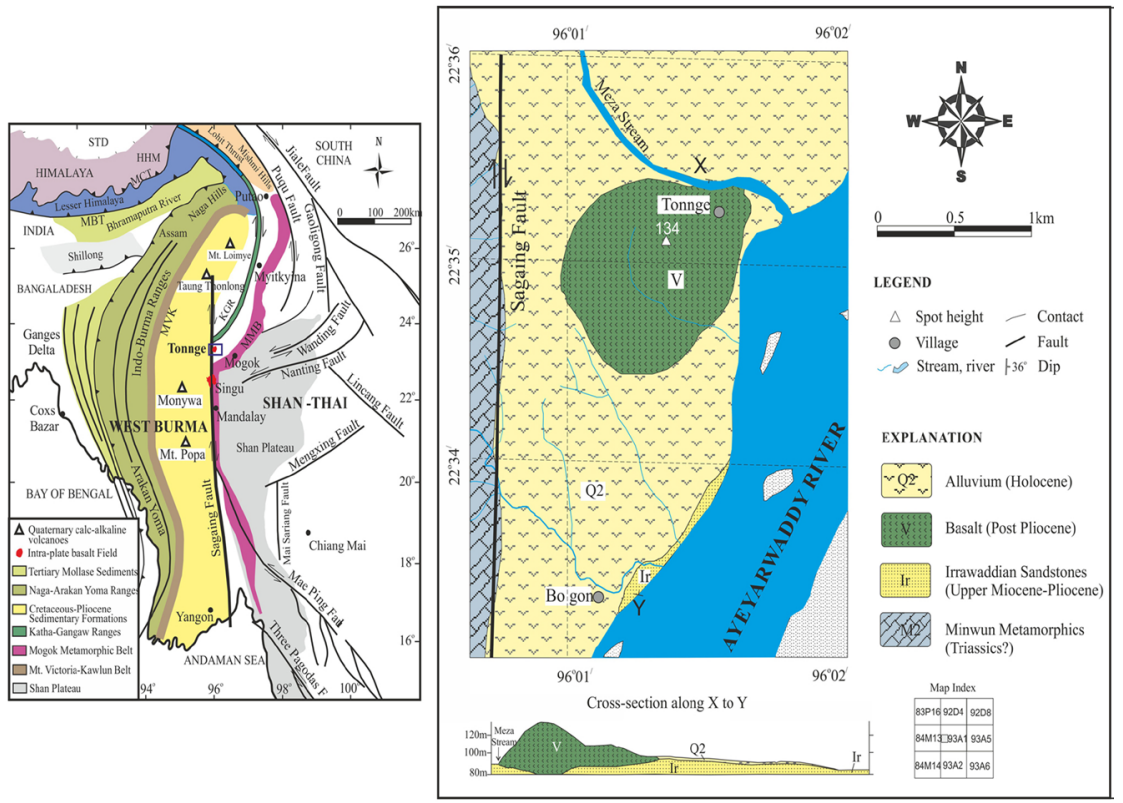

(a)

(b)

Figure 1. (a) Simplified geological map showing structural elements, Tertiary volcanoes and basalt fields in Myanmar and related regions (modified from Searle et al. [1]; Lee et al. [3]). Inset refers to the principal terrane boundaries and Cenozoic tectonic extrusion in East Asia related with the India-Asia collision. HHM = High Himalayan Metamorphics. LHS = Lesser Himalayan Metasedimentary Series. STDS $=$ South Tibet Detachment System. MCT = Main Central Thrust. MBT = Main Boundary Thrust; (b) Geological map of the Tonnge area, Tigyaing Township, Sagaing Region, Myanmar [8]. 
basaltic field situated $100 \mathrm{~km}$ north of Mandalay, in Tigyaing Township, Sagaing Region of Myanmar. This basaltic field is located to the north of Singu-Kabwet basaltic lava field that poured out from the fissure along the prominent dextral Sagaing Fault of Myanmar. The basaltic field of Tonnge area, however, contains relatively small volume, predominantly monogenetic lava flows compared to the Singu-Kabwet area. Detailed petrological and geochemical studies of the Tonnge basalts are still lacking till date to constrain the petrogenesis and evolution of the basaltic lava. This paper documents the petrography and geochemical data for the basaltic lavas in order to elucidate the characteristics of basalts, magmatic processes during their genesis and implications on their emplacement.

\section{Geology of the Tonnge Basalt}

The basaltic field in the Tonnge area displays a general circular outline (Figure 1(b)) and consists of basaltic lava flows with rare volcaniclastics which are likely to be erupted from a centralvent. The volcanic center is probably located in the northeastern part of the Tonge Hill where central vent eruptions of lava initiated and further spread out laterally to the south-southwest direction. The basaltic lavas rest upon the clastic sediments (sandstones) of Irrawaddy Formation (Upper Miocene-Pliocene) over an area of approximately $2 \mathrm{~km}^{2}$. Therefore, the basaltic lava field is considered to be produced in post-Pliocene period. The geological map of Tonnge area is shown in Figure 1(b) [8].

The basaltic lava flows are generally less than $5 \mathrm{~m}$ thick (Figure 2(a)). The flows in the southern and southeastern parts of the Tonnge Hill are represented
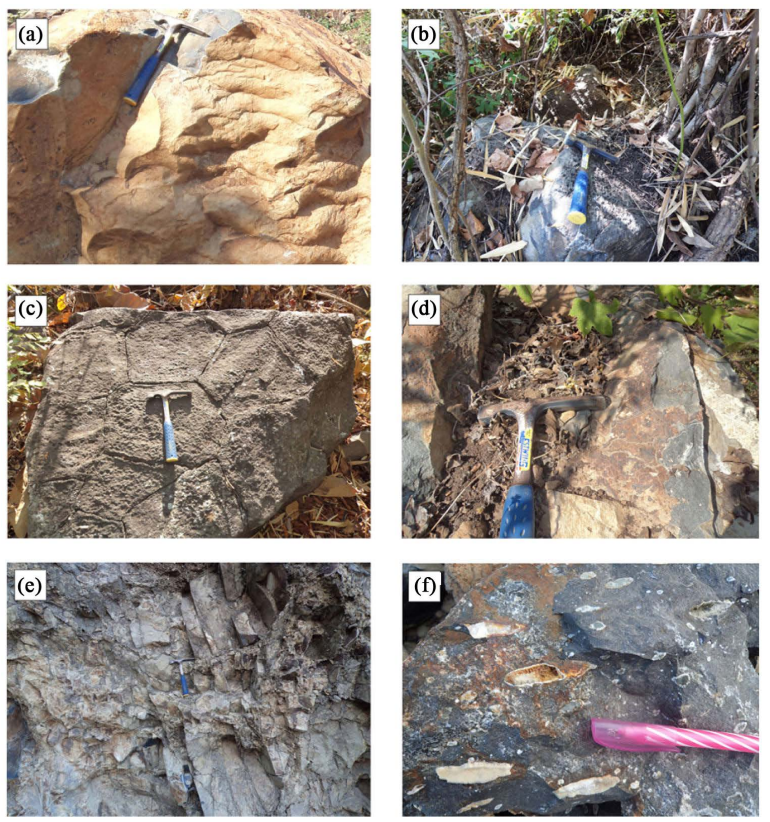

Figure 2. Field photographs of (a) basalt showing the flow nature; (b) vesicular basalt; (c) polygonal columnar jointing in the basalt; (d) iron oxides coating on the surface of basalt outcrop; (e) dyke-like intrusion of columnar basalt and (f) parallel elongated amygdales in the basalt filled by zeolites. 
by bluish grey to dark grey vesicular lavas in the upper part (Figure 2(b)) with polygonal columnar joints (probably entablature) and dense masses in the lower part. Vertical columns are generally 4 - to 6 -sided and 0.3 to $0.5 \mathrm{~m}$ across (Figure $2(\mathrm{c})$ ). The characteristic blocky and massive lavas are mostly confined to the remaining parts of the Tonnge area. Irregular blocky or prismatic jointing is also observed in these basaltic lavas. The fresh surface of the basalts is usually bluish to dark grey. The surfaces of the lava blocks are often coated by reddish brown iron oxides (Figure 2(d)).

Localized dyke-like intrusion (Figure $2(\mathrm{e})$ ) is observed in the central-eastern part of the Tonnge Hill. In this part, basaltic lava exhibits vesiculation features containing abundant amygdaloidal infillings (Figure 2(f)). Vesicles are developed when dissolved gases are released during the ascent of lava due to pressure drop, forming gas bubbles (the cavities) in the upper part of the lava flow. The cavities in the basalts are perfect rounded or elliptical in shape and range from 1 $10 \mathrm{~cm}$ in diameter. Those vesicles are filled with secondary minerals due to near-surface circulation of meteoric water. Common amygdale minerals are quartz, calcite, and zeolites.

\section{Analytical Techniques}

About fifty basalt samples (average size $12 \mathrm{~cm} \times 10 \mathrm{~cm} \times 8 \mathrm{~cm}$ ) were collected from Tonnge area. Of these, 25 samples were prepared for thin-sections and studied under polarizing microscope in order to determine the mineralogical composition and textural characteristics. The major and trace elemental compositions of twelve basalt samples were analyzed by X-Ray Fluorescence (XRF) from pressed pellets using a RIGAKU RIX-3100 (Series VR 25006), with relative standard deviations $<5 \%$. For quality control, the reference sample JA-3 was used as standard sample. The XRF analyses were performed at the Department of Earth Resources Engineering, Faculty of Engineering, Kyushu University (Japan) and the $\mathrm{X}$-ray machine is operated at $50 \mathrm{kV}$ and $50 \mathrm{~mA}$, scanning speed: automatic and $4 \%$ min for the determination of major and trace elemental compositions. The loss on ignition (LOI) was measured for all samples by weight difference after ignition at $1000^{\circ} \mathrm{C}$

\section{Result and Discussion}

\subsection{Petrography}

The basalts from Tonnge area are porphyritic, holocrystalline and consist of phenocrysts of olivine, plagioclase \pm clinopyroxene. Olivine is the dominant mineral phase in the studied basalt samples. Phenocrysts of olivine are usually subhedral to euhedral (Figures 3(a)-(e)), unzoned and are often characteristically marked by corroded and embayed margins (Figure 3(a)), due to resorption of the crystals by reaction with surrounding liquid. Some phenocrysts exhibit skeletal texture (Figure 3(c)). A cluster of olivine and plagioclase phenocrysts often develops distinct glomeroporphyritic texture (Figure 3(b)). 

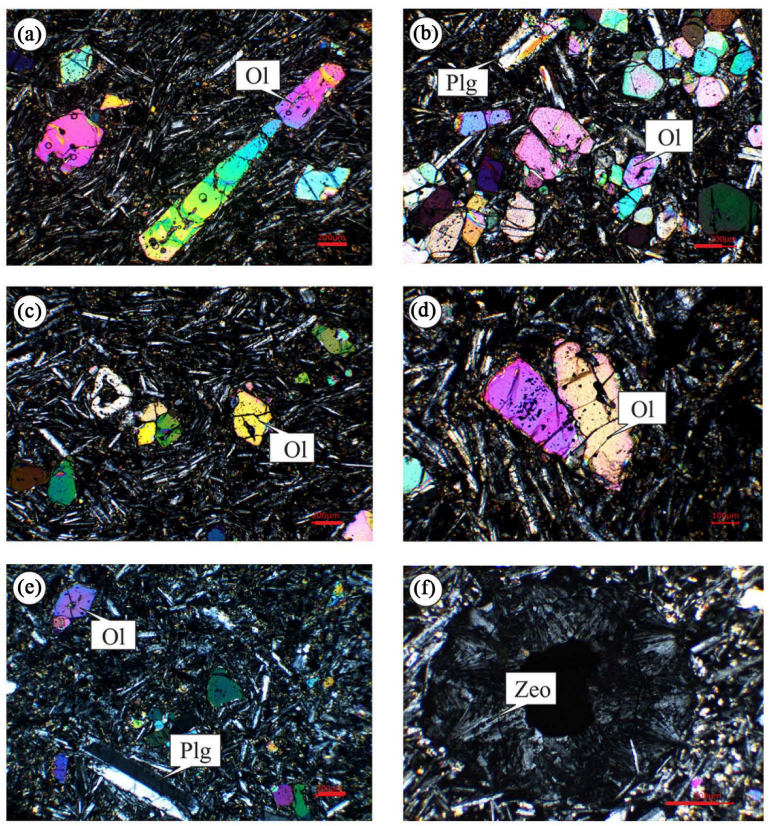

Figure 3. Photomicrographs showing common textures in the basalts (a) parallel-growth crystals of olivine (elongate) and embayed phenocryst (purple) aligned and embedded in the trachytic groundmass; (b) clustered olivine phenocrysts with minor plagioclase phenocrysts enclosed by intergranular groundmass of plagioclase, olivine and pyroxene developing glomeroporphyritic texture; (c) skeletal olivine phenocrysts in the sub-parallel plagioclase microlites; (d) Small opaque inclusions in two large olivine phenocrysts with corroded margins; (e) phenocrysts of plagioclase (labradorite) and micro-phenocrysts of olivine in different sizes set in fine-grained groundmass developing seriate texture; (f) zeolite filling in the amygdule of basalt.

Small inclusions of opaque minerals (probably Ti-Fe oxides) are occasionally observed in the phenocrysts of olivine (Figure 3(d)). Partial or complete replacements of iddingsite are observed around the edges and along the cracks of some olivine phenocrysts. They are secondary constituents resulted from the hydrous alteration of the primary mafic minerals. Phenocrysts of plagioclase (principally labradorite) are euhedral to subhedral (Figure 3(e)). The groundmass is intergranular and consists predominantly of microlites of plagioclase with subordinate olivine, clinopyroxene, and opaque minerals such as titanomagnetite and ilmenite (Figures 3(a)-(d)). Parallel and sub-parallel orientation (trachytic) of plagioclase microlites is commonly observed (Figure 3(a), Figure $3(c)$, Figure $3(d)$ ) in the basalt samples. The amygdales in amygdaloidal basalts are often filled with secondary minerals such as quartz, calcite, and zeolite minerals (Figure 3(f)).

\subsection{Whole Rock Geochemistry}

Major and trace elemental compositions of the basalt samples from the Tonnge area are shown in Table 1 . The studied samples show silica content ranging from 49.01 to $50.87 \mathrm{wt} \%$, low to moderate $\mathrm{MgO}$ and $\mathrm{CaO}$ (4.39 to $5.33 \mathrm{wt} \%$ and 7.96 to $8.47 \mathrm{wt} \%$ respectively). $\mathrm{Al}_{2} \mathrm{O}_{3}$ contents of the samples show a narrow 
Table 1. Whole-rock major- and trace-element compositions for basalts of Tonnge area.

\begin{tabular}{|c|c|c|c|c|c|c|c|c|c|c|c|c|}
\hline Sample ID & Tn-01 & Tn-02 & Tn-03 & Tn-04 & Tn-05 & $\operatorname{Tn}-06$ & Tn-07 & Tn-08 & Tn-09 & Tn-am & Tn-am 1 & $\mathrm{TN}-\mathrm{am} 3$ \\
\hline $\mathrm{SiO}_{2}$ & 50.74 & 50.56 & 50.42 & 50.62 & 50.56 & 50.69 & 50.87 & 50.55 & 50.34 & 49.63 & 50.36 & 49.01 \\
\hline $\mathrm{TiO}_{2}$ & 2.01 & 2.00 & 2.03 & 2.01 & 1.99 & 2.03 & 2.02 & 2.03 & 2.07 & 1.99 & 2.04 & 2.01 \\
\hline $\mathrm{Al}_{2} \mathrm{O}_{3}$ & 17.71 & 17.65 & 16.92 & 17.51 & 17.61 & 17.38 & 17.86 & 17.63 & 17.50 & 17.19 & 17.33 & 16.61 \\
\hline $\mathrm{FeO}$ & 8.94 & 8.92 & 8.95 & 8.89 & 8.81 & 9.03 & 9.15 & 9.03 & 9.19 & 8.80 & 9.15 & 8.84 \\
\hline $\mathrm{MnO}$ & 0.17 & 0.17 & 0.17 & 0.17 & 0.17 & 0.17 & 0.17 & 0.17 & 0.17 & 0.17 & 0.17 & 0.17 \\
\hline $\mathrm{MgO}$ & 4.46 & 4.46 & 5.33 & 4.63 & 4.39 & 4.83 & 4.56 & 4.55 & 4.60 & 4.80 & 5.04 & 5.03 \\
\hline $\mathrm{CaO}$ & 8.02 & 8.07 & 7.96 & 8.20 & 8.01 & 8.42 & 8.11 & 8.28 & 8.16 & 8.04 & 8.47 & 8.00 \\
\hline $\mathrm{Na}_{2} \mathrm{O}$ & 3.36 & 3.34 & 2.82 & 2.98 & 3.33 & 2.62 & 3.41 & 2.88 & 3.11 & 2.64 & 2.24 & 2.24 \\
\hline $\mathrm{K}_{2} \mathrm{O}$ & 2.36 & 2.32 & 2.27 & 2.47 & 2.31 & 2.45 & 2.32 & 2.44 & 2.38 & 2.52 & 2.71 & 2.69 \\
\hline $\mathrm{P}_{2} \mathrm{O}_{5}$ & 0.61 & 0.58 & 0.59 & 0.60 & 0.60 & 0.64 & 0.59 & 0.60 & 0.60 & 0.58 & 0.59 & 0.55 \\
\hline L.O.I & 1.36 & 1.69 & 2.30 & 1.66 & 1.97 & 1.46 & 0.68 & 1.56 & 1.60 & 3.35 & 1.62 & 4.54 \\
\hline $\mathrm{V}$ & 208 & 208 & 211 & 211 & 209 & 218 & 220 & 207 & 231 & 215 & 219 & 209 \\
\hline $\mathrm{Cr}$ & 173 & 170 & 175 & 173 & 173 & 174 & 177 & 185 & 181 & 192 & 178 & 177 \\
\hline Co & 58 & 47 & 56 & 59 & 60 & 52 & 120 & 61 & 60 & 52 & 85 & 81 \\
\hline $\mathrm{Ni}$ & 60 & 59 & 63 & 61 & 59 & 61 & 63 & 62 & 63 & 62 & 65 & 67 \\
\hline $\mathrm{Sb}$ & 28 & 17 & 17 & 24 & 21 & 15 & 20 & 23 & 22 & 25 & 18 & 22 \\
\hline Sn & 23 & 19 & 14 & 25 & 20 & 20 & 19 & 25 & 26 & 20 & 24 & 15 \\
\hline $\mathrm{W}$ & 34 & 0 & 18 & 30 & 19 & 0 & 260 & 18 & 13 & 9 & 17 & 9 \\
\hline Mo & 8 & 6 & 7 & 8 & 7 & 8 & 9 & 10 & 7 & 10 & 8 & 12 \\
\hline $\mathrm{Rb}$ & 59 & 59 & 62 & 57 & 57 & 59 & 58 & 57 & 57 & 64 & 73 & 75 \\
\hline $\mathrm{Sr}$ & 816 & 818 & 849 & 869 & 818 & 867 & 969 & 966 & 926 & 1092 & 900 & 1287 \\
\hline $\mathrm{Ba}$ & 727 & 701 & 699 & 705 & 713 & 710 & 677 & 725 & 712 & 723 & 718 & 737 \\
\hline $\mathrm{Y}$ & 28 & 26 & 27 & 26 & 26 & 27 & 26 & 27 & 30 & 27 & 29 & 28 \\
\hline $\mathrm{Zr}$ & 186 & 181 & 184 & 182 & 181 & 187 & 187 & 187 & 192 & 181 & 190 & 181 \\
\hline $\mathrm{Nb}$ & 53 & 51 & 53 & 53 & 52 & 54 & 53 & 54 & 55 & 53 & 53 & 55 \\
\hline $\mathrm{Th}$ & 9 & 8 & 9 & 8 & 9 & 9 & 9 & 12 & 11 & 9 & 8 & 11 \\
\hline $\mathrm{Mg}^{\#}$ & 47 & 47 & 52 & 48 & 47 & 49 & 47 & 47 & 47 & 49 & 50 & 50 \\
\hline $\mathrm{Na}_{2} \mathrm{O}+\mathrm{K}_{2} \mathrm{O}$ & 5.72 & 5.66 & 5.09 & 5.45 & 5.64 & 5.07 & 5.73 & 5.32 & 5.49 & 5.16 & 4.96 & 4.93 \\
\hline $\mathrm{K}_{2} \mathrm{O} / \mathrm{P}_{2} \mathrm{O}_{5}$ & 3.85 & 3.99 & 3.86 & 4.11 & 3.87 & 3.82 & 3.93 & 4.03 & 3.98 & 4.34 & 4.62 & 4.85 \\
\hline \multicolumn{13}{|l|}{$\begin{array}{l}\text { Normative } \\
\text { minerals }\end{array}$} \\
\hline Or & 13.95 & 13.71 & 13.41 & 14.6 & 13.65 & 14.48 & 13.71 & 14.42 & 14.06 & 14.89 & 16.01 & 15.9 \\
\hline $\mathrm{Ab}$ & 28.43 & 28.26 & 23.86 & 25.22 & 28.18 & 22.17 & 28.85 & 24.37 & 26.32 & 22.34 & 18.95 & 18.95 \\
\hline An & 26.27 & 26.32 & 26.81 & 27.11 & 26.28 & 28.43 & 26.57 & 27.97 & 26.76 & 27.61 & 29.23 & 27.32 \\
\hline Di & 7.94 & 8.27 & 7.31 & 8.03 & 7.94 & 7.61 & 8.17 & 7.65 & 8.16 & 7.04 & 7.42 & 7.27 \\
\hline Hy & 5.21 & 5 & 14.7 & 9.65 & 6.28 & 15.87 & 3.73 & 11.26 & 7.1 & 12.91 & 17.4 & 16.33 \\
\hline $\mathrm{Ol}$ & 11.34 & 11.36 & 6.13 & 8.27 & 10.27 & 4.36 & 12.82 & 7.24 & 10.39 & 6.43 & 3.83 & 4.28 \\
\hline Il & 3.82 & 3.8 & 3.86 & 3.82 & 3.78 & 3.86 & 3.84 & 3.86 & 3.93 & 3.78 & 3.87 & 3.82 \\
\hline Ap & 1.41 & 1.34 & 1.37 & 1.39 & 1.39 & 1.48 & 1.37 & 1.39 & 1.39 & 1.34 & 1.37 & 1.27 \\
\hline $\operatorname{Pr}$ & 0.02 & 0.02 & 0.02 & 0.02 & 0.02 & 0.02 & 0.02 & 0.02 & 0.02 & 0.02 & 0.02 & 0.02 \\
\hline
\end{tabular}

Note: L.O.I-Loss on ignition. 
range between 16.61 and $17.86 \mathrm{wt} \%$. The $\mathrm{K}_{2} \mathrm{O}$ contents in the samples range from 2.27 to $2.71 \mathrm{wt} \%$. They have high $\mathrm{FeO}$ content ( 8.8 to $9.19 \mathrm{wt} \%$ ). It is observed that two samples (namely Tn-Am and Tn-Am3) have high LOI values (3.35 and $4.54 \mathrm{wt} \%$ respectively). The $\mathrm{TiO}_{2}$ contents range from 1.99 to 2.07 wt $\%$. The basaltic rocks having $\mathrm{TiO}_{2} \geq 2 \mathrm{wt} \%$ are recognized as high-Ti basalts and they are considered to be the plume-related basalts erupted in both continental and oceanic environments [9] [10] [11]. Tonnge basalts are classified as high Ti-basalts $\left(\mathrm{TiO}_{2} \geq 2 \mathrm{wt} \%\right)$ because most samples have $\mathrm{TiO}_{2}$ greater than 2 .

Contents of compatible elements ( $\mathrm{Ni}$ and $\mathrm{Cr}$ ) range from 59 - $67 \mathrm{ppm}$ and 170 - $192 \mathrm{ppm}$, respectively. These values are relatively lower than that of primary mantle melt (i.e. $\mathrm{Ni}>200 \mathrm{ppm}, \mathrm{Cr}>400 \mathrm{ppm}$ ). There is a positive correlation between decreasing $\mathrm{Ni}$ and $\mathrm{Cr}$ with $\mathrm{MgO}$ (Table 1). High ratios of $\mathrm{K}_{2} \mathrm{O} / \mathrm{P}_{2} \mathrm{O}_{5}$ $\left(\mathrm{K}_{2} \mathrm{O} / \mathrm{P}_{2} \mathrm{O}_{5}>2\right)$ are observed. Basalts have relatively higher contents of $\mathrm{Rb}(57$ $75 \mathrm{ppm}) \mathrm{Ba}(677-737 \mathrm{ppm})$ and $\mathrm{Sr}(816-1092 \mathrm{ppm})$ as compared to those of Oceanic Island Basalts (OIB) (Rb-31 ppm; Ba-350 ppm: Sr-660 ppm). Nb contents (51- $55 \mathrm{ppm}$ ) are fairly higher if compared to that of OIB (Nb: $48 \mathrm{ppm}$ ).

The Mg-numbers of the basalt samples range from 47 to 52. CIPW normative compositions of the basalts are calculated and presented in Table 1. Normative compositions of the basalts are marked by the presences of diopside ( 7.04 to 8.27 wt\%), olivine (3.83 to $12.82 \mathrm{wt} \%$ ), and hypersthene (3.73 to $17.4 \mathrm{wt} \%$ ). The silica-undersaturated character of the basalts can be inferred from normative mineralogy.

In the total alkali $\left(\mathrm{Na}_{2} \mathrm{O}+\mathrm{K}_{2} \mathrm{O}\right)$ vs. silica $\left(\mathrm{SiO}_{2}\right)$ diagrams (Figure 4(a)) [12], the basaltic samples fall within the field of trachy-basalt and show an alkaline composition. In the $\mathrm{K}_{2} \mathrm{O}$ vs. $\mathrm{SiO}_{2}$ diagram (Figure 4(b)) [13], magmatic affanity of the basalts shows absorakite (shoshonitic). In Harker' variation diagram (Figure 5), the basalts are characterized by increasing $\mathrm{Al}_{2} \mathrm{O}_{3}$, and $\mathrm{Na}_{2} \mathrm{O}$ with decreasing $\mathrm{SiO}_{2}$. In contrast, $\mathrm{K}_{2} \mathrm{O}$ and $\mathrm{MgO}$ contents show negative correlation

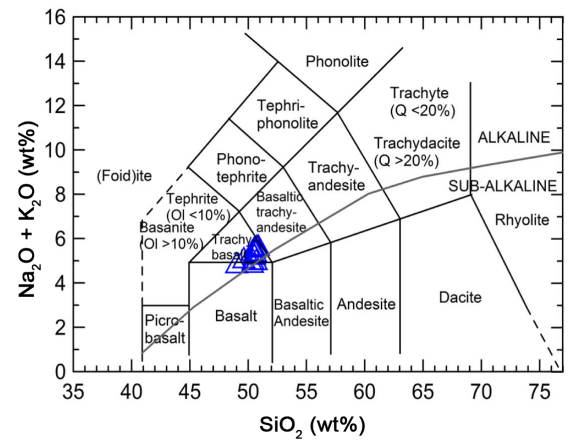

(a)

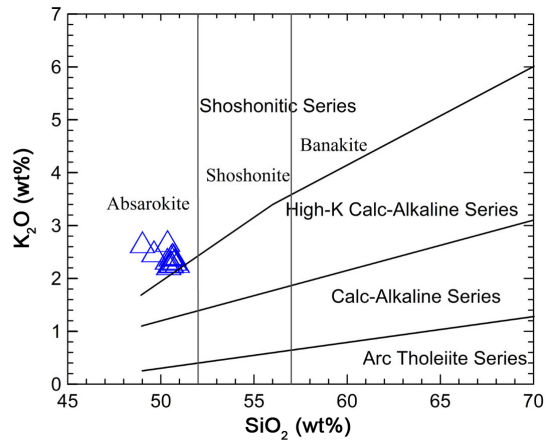

(b)

Figure 4. (a) Total alkali $\left(\mathrm{Na}_{2} \mathrm{O}+\mathrm{K}_{2} \mathrm{O}\right)$ vs. silica $\left(\mathrm{SiO}_{2}\right)$ diagram [12] showing the basalt samples from Tonnge area in the field of trachy basalt. The line separating the sub-alkaline and alkaline subdivisions was after Irvine and Baragar [14]; (b) $\mathrm{K}_{2} \mathrm{O}$ vs. $\mathrm{SiO}_{2}$ variation diagram [13] showing the alkaline composition of Tonnge basalts. The classification for $\mathrm{K}_{2} \mathrm{O}-\mathrm{SiO}_{2}$ contents and shoshonitic series was after Gill [15], and Peccerillo and Taylor [13], respectively. 

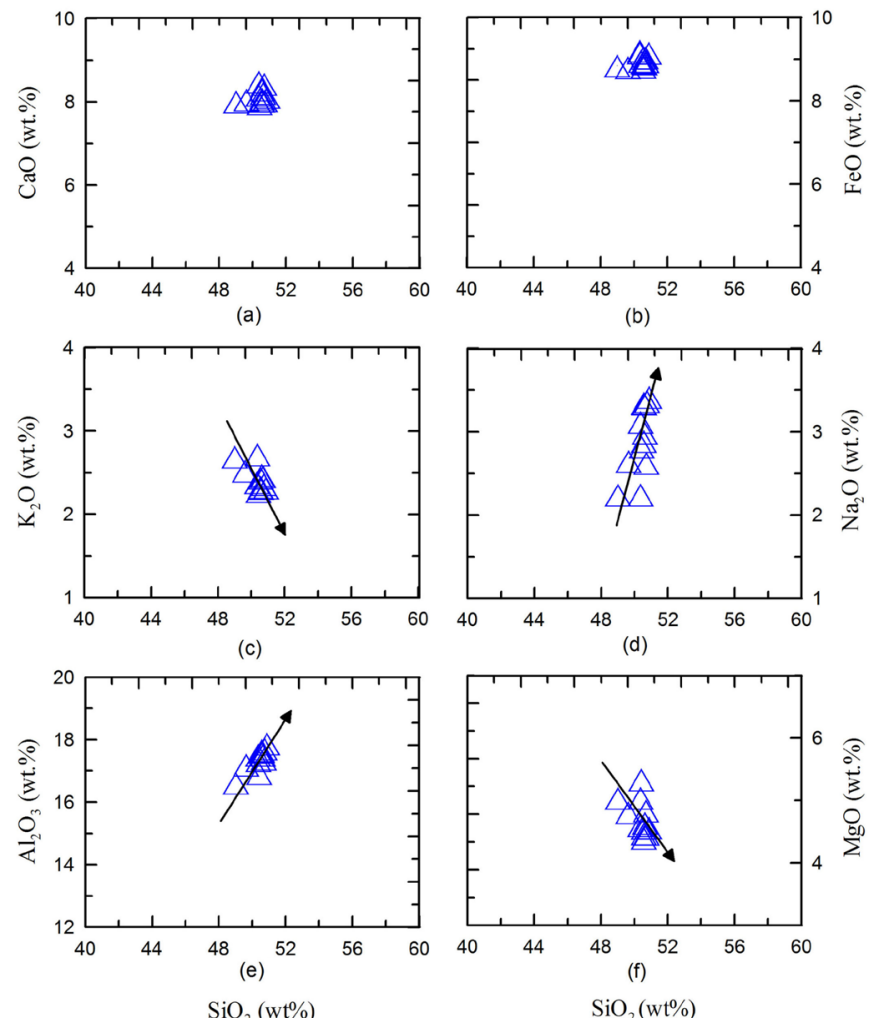

$\mathrm{SiO}_{2}(\mathrm{wt} \%)$

Figure 5. Plots of major elements vs. $\mathrm{SiO}_{2}$ (Harker diagram) for Tonnge basalt samples.

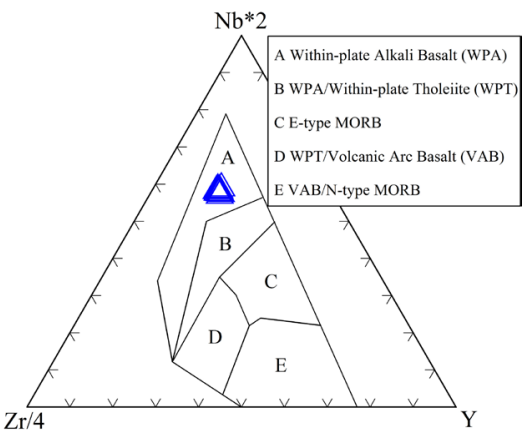

(a)

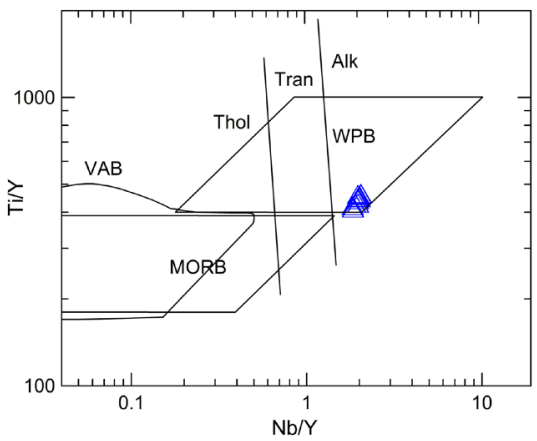

(a)

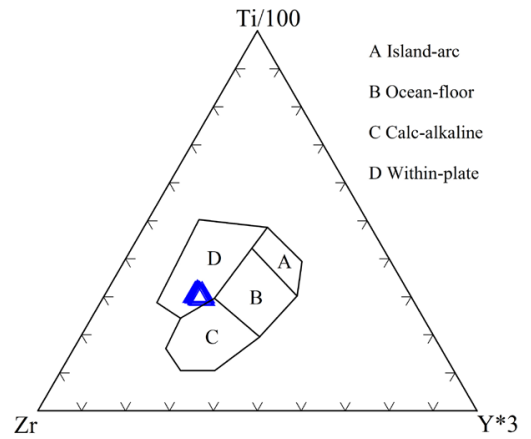

(b)

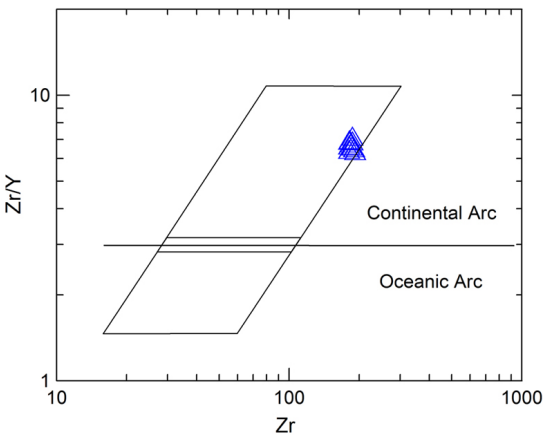

(b)

Figure 6. Tectonic discrimination diagrams for basalts from Tonnge area (a) Nb-Zr-Y diagram [16]; (b) Ti-Zr-Y diagram [17]; (c) Nb/Y-Ti/Y diagram [18] and (d) Zr vs. Zr/Y diagram [19]. 
with $\mathrm{SiO}_{2}$ contents. It indicates that possible fractionation of early formed mafic minerals such as olivine occurs during evolution of magma and no apparent fractional crystallization involved during the ascent of the basaltic magma.

Incompatible trace element abundances and HFSE ratios are considered as suitable parameters in order to discriminate the tectonic environment for the eruption of basaltic magmas. The basalt samples are plotted on the various tectonic discrimination diagrams such as Nb-Zr- $\mathrm{Y}, \mathrm{Ti}-\mathrm{Zr}-\mathrm{Y}, \mathrm{Nb} / \mathrm{Y}-\mathrm{Ti} / \mathrm{Y}$ and $\mathrm{Zr}$ vs. $\mathrm{Zr} / \mathrm{Y}$ (Figures 6(a)-(d)). In the plot of Nb-Zr-Y diagram (Figure 6(a)) [16], all basalt samples are plotted in the field of the within-plate alkali basalt (WPA). The plots of these samples also cluster in the field of within plate basalts on the Ti-Zr-Y (Figure 6(b)) [17] and Nb/Y-Ti/Y diagrams (Figure 6(c)) [18]. On $\mathrm{Zr}-\mathrm{Zr} / \mathrm{Y}$ diagram, it is possible to discriminate the basalts of Tonnge area as continental basalt (Figure 6(d)) [19].

\section{Conclusions}

Petrographical studies of basalts from the Tonnge area indicated that they were composed primarily of olivine, plagioclase and pyroxene. They were classified as olivine basalt as olivine was considered to be the most common essential mineral phase, followed by other minerals such as plagioclase, pyroxene, and Fe- $\mathrm{Ti}$ oxides. Absence of quartz and presence of fairly abundant olivine (as both phenocrysts and groundmass) in the studied samples indicated that they were typical alkali olivine basalts [20].

Geochemical and tectonic discrimination diagrams indicated that the basaltic lavas were formed by the eruption from central vent in the continental intraplate setting. The unique geochemical characteristics of basalts indicated that they were derived from the discrete magma batch as a result of partial melting of continental lithospheric mantle source and evolved independently by variable degrees of fractional crystallization. The abundance of olivine phenocrysts in the basalts suggested that the melt has ascended from its source and subsequently detained in the magma chamber and phenocrysts were settled down during subsequent ascent. A positive correlation between decreasing $\mathrm{Ni}$ and $\mathrm{Cr}$ with respect to decreasing $\mathrm{MgO}$ suggested that fractionation of olivine and clinopyroxene occurred during the evolution of the basaltic magma. The higher ratios of $\mathrm{K}_{2} \mathrm{O} / \mathrm{P}_{2} \mathrm{O}_{5}$ in the basalts pointed to the fact that assimilation of magma with the silicic crystal component or with wall rocks occurred during their emplacement and/or ascent as within-plate basalt in the continental setting.

\section{Acknowledgements}

The authors would like to express sincere thanks to Head of the village of Tonnge, Tigyaing Township, Sagaing Region (Myanmar) for his kind support during field investigation in the Tonngearea.

\section{Conflicts of Interest}

The authors declare no conflicts of interest regarding the publication of this paper. 


\section{References}

[1] Searle, M.P., Noble, S.R., Cottle, J.M., Waters, D.J., Mitchell, A.H.G., Hlaing, T. and Horstwood, M.S.A. (2007) Tectonic Evolution of the Mogok Metamorphic Belt, Burma (Myanmar) Constrained by U-Th-Pb Dating of Metamorphic and Magmatic Rocks. Tectonics, 26, TC2083. https://doi.org/10.1029/2006TC002083

[2] Mitchell, A.H.G., Htay, M.T., Htun, K.M., Win, M.N., Oo, T. and Hlaing, T. (2007) Rock Relationships in the Mogok Metamorphic Belt, Tatkon to Mandalay, Central Myanmar. Journal of Asian Earth Sciences, 29, 891-910.

https://doi.org/10.1016/j.jseaes.2006.05.009

[3] Lee, H.-Y., Chung, S.-L. and Yang, H.-M. (2016) Late Cenozoic Volcanism in Central Myanmar: Geochemical Characteristics and Geodynamic Significance. Lithos, 245, 174-190.

[4] Liu, C.-Z., Chung, S.-L., Wu, F.-Y., Zhang, C., Xu, Y., Wang, J.-G., Chen, Y. and Guo, S. (2016) Tethyan Suturing in Southeast Asia: Zircon U-Pb and Hf-O Isotopic Constraints from Myanmar Ophiolites. Geology, 44, 311-314. https://doi.org/10.1130/G37342.1

[5] Gardiner, N.J., Robb, L.J. and Searle, M.P. (2014) The Metallogenic Provinces of Myanmar. Applied Earth Science, 123, 25-38. https://doi.org/10.1179/1743275814Y.0000000049

[6] Bertrand, G., Rangin, C., Maury, R.C., Htun, H.M., Bellon, H., Guillaud, J.P. (1998) The Singu Basalt (Myanmar): New Constraints for the Amount of Recent Offset on the Sagaing Fault. Earth and Planetary Sciences, 327, 479-484. https://doi.org/10.1016/S1251-8050(99)80076-7

[7] Maury, R.C., Pubellier, M., Rangin, C., Wulput, L., Cotton, J., Socquet, A., Bellon, H., Guillaud, J.P. and Htun, H.M. (2004) Quaternary Calc-Alkaline and Alkaline Volcanism in an Hyperoblique Convergence Setting, Central Myanmar and Western Yunnan. Bulletin de la Societe Geologique de France, 175, 461-472. https://doi.org/10.2113/175.5.461

[8] Theingi, M. (2018) Petrology and Tectonic Significance of Basaltic Rocks from Tonnge Area, Sagaing Region. University of Mandalay, Mandalay, Myanmar.

[9] Safonova, I.Y. (2009) Intraplate Magmatism and Oceanic Plate Stratigraphy of the Paleo-Asian and Paleo-Pacific Oceans from 600 to 140 Ma. Ore Geology Reviews, 35, 137-154. https://doi.org/10.1016/j.oregeorev.2008.09.002

[10] Simonov, V.A., Mikolaichuk, A.V., Safonova, I.Y., Kotlyarov, A.V. and Kovyazin, S.V. (2014) Late Paleozoic-Cenozoic Intra-Plate Continental Basaltic Magmatism of the Tienshan-Junggar Region in the SW Central Asian Orogenic Belt. Gondwana Research, 27, 1646-1666. https://doi.org/10.1016/j.gr.2014.03.001

[11] Manikyamba, C., Ganguly, S., Santosh, M., Saha, A. and Lakshminarayana, G. (2015) Geochemistry and Petrogenesis of Rajahmundry Trap Basalts of Krishna-Godavari Basin, India. Geoscience Frontiers, 6, 437-451. https://doi.org/10.1016/j.gsf.2014.05.003

[12] Bas, M.J.L., Maitre, R.W.L., Streckeisen, A. and Zanettin, B. (1986) A Chemical Classification of Volcanic Rocks Based on the Total Alkali-Silica Diagram. Journal of Petrology, 27, 745-750. https://doi.org/10.1093/petrology/27.3.745

[13] Peccerillo, A. and Taylor, S.R. (1976) Geochemistry of Eocene Calc-Alkaline Volcanic Rocks from Kastamonu Area, Northern Turkey. Contributions to Mineralogy and Petrology, 58, 63-81. https://doi.org/10.1007/BF00384745

[14] Irvine, T.N. and Baragar, W.R.A. (1971) A Guide to the Chemical Classification of 
the Common Volcanic Rocks. Canadian Journal of Earth Sciences, 8, 523-548. https://doi.org/10.1139/e71-055

[15] Gill, J.B. (1981) Orogenic Andesite and Plate Tectonics. Springer-Verlag, Berlin, 390. https://doi.org/10.1007/978-3-642-68012-0

[16] Meschede, M. (1986) A Method of Discrimination between Different Types of Mid-Ocean Ridge Basalts and Continental Tholeiites with the Nb-Zr-Y Diagram. Chemical Geology, 56, 207-218. https://doi.org/10.1016/0009-2541(86)90004-5

[17] Pearce, J.A. and Cann, J.R. (1973) Tectonic Setting of Basic Volcanic Rocks Determined Using Trace Element Analyses. Earth and Planetary Science Letters, 19, 290-300. https://doi.org/10.1016/0012-821X(73)90129-5

[18] Pearce, J.A. (1982) Trace Element Characteristics of Lavas from Destructive Plate Boundaries. In: Thorpe, R.S., Ed., Andesites, Wiley, Chichester, 525-548.

[19] Pearce, J.A. and Norry, M.J. (1979) Petrogenetic Implications of Ti, Zr, Y, and Nb Variations in Volcanic Rocks. Contributions to Mineralogy and Petrology, 69, 33-47. https://doi.org/10.1007/BF00375192

[20] Odat, S. (2014) Mineralogy and the Texture of the Basalt in Hail Region, Saudi Arabia. Open Journal of Geology, 4, 198-205. https://doi.org/10.4236/ojg.2014.45015 